\title{
SALIVARY PROTEIN AND GLUCOSE LEVELS IN DIABETIC AND NON-DIABETIC PATIENTS - A REVIEW
}

\section{HANSHIKA RAVI, SOHARA PARVIN}

Department of Biochemistry, Saveetha Dental College, Chennai, Tamil Nadu, India. Email: Hanshikaravi98@gmail.com

Received: 04 June 2018, Revised and Accepted: 24 August 2018

\begin{abstract}
Saliva is the most important tool to monitor various biochemical parameters including protein and glucose. Hence, it can be used as a tool to find if a patient is diabetic or nondiabetic. This review presents information about the salivary glucose and protein levels in diabetic and non-diabetic subjects. It can be concluded that salivary protein and glucose levels are raised in diabetic patients than in non-diabetic patients.
\end{abstract}

Keywords: Saliva, Salivary protein, Salivary glucose, Diabetes mellitus

(C) 2019 The Authors. Published by Innovare Academic Sciences Pvt Ltd. This is an open access article under the CC BY license (http://creativecommons. org/licenses/by/4. 0/) DOI: http://dx.doi.org/10.22159/ajpcr.2019.v12i1.13271

\section{INTRODUCTION}

Diabetes mellitus (DM) is a complex multisystemic metabolic disorder characterized by a relative or absolutely insufficient insulin secretion and/or associated resistance to metabolic action of insulin on target tissues [1]. It is a massive, growing, silent epidemic that has the potential to cripple health services in all parts of the world. It can be defined as a group of chronic diseases characterized by insulin deficiency, cellular resistance to insulin action, or both, resulting in hyperglycemia and other related metabolic disturbances [3]. It is classified, according to its etiology, as type 1 and type 2 . Type 1 results in the destruction of the beta cells of the pancreas causing an absolute deficiency of insulin, while type 2 diabetes results from cellular dysfunction in resistance to insulin by peripheral tissue [2]. The number of people diagnosed with diabetes is increasing at an alarming rate. It is estimated that, by the year 2030, 366 million people worldwide will have the disease. Based on the diabetes atlas, the highest numbers of patients are currently found mainly in western countries, such as in the European region and the Western Pacific region. This, however, will change in the year 2025 where the greatest number of diabetic patients is expected to be from the Asian region [5]. A recent clinical study showed that gingival bleeding is significantly increased in children with poorly controlled type 1 diabetes compared with nondiabetic controls [9]. The aim of this present study is to spread knowledge about the salivary protein and glucose levels in diabetic patients.

\section{HUMAN SALIVA AS A BIOMARKER}

Blood is the most commonly used sample for laboratory diagnostic procedures, but it requires frequent invasion to vessels to collect the sample and it also causes unnecessary discomfort and mental trauma to patients; therefore, a much simpler and non-invasive technique for the diagnosis and monitoring of diabetes is very desirable [4]. Hence, saliva was chosen as the sample for study because many reports have suggested that saliva can be an alternative to blood. It is also considered as essential for diagnostic laboratory analysis. Certain immunological parameters in saliva may be related with perceived oral health [9]. The value of saliva as a biological fluid for the detection of diagnostic and prognostic biomarkers has become increasingly well established [10]. Saliva is an organic fluid that can indicate local and systemic alterations, such that the components of saliva can be related to hormonal, neurological, nutritional, immunological, and metabolic state of the individual [2]. Furthermore, its collection is non-invasive compared to the collection of other body fluids and hence has a great potential for use in the diagnosis of systemic and localized diseases [5]. It is easy to handle and may be repeated without initiating much discomfort to the subjects [10]. Higher salivary glucose concentrations are associated with increased oral candidal carriage in diabetic subjects. It has also been reported that evaluation of salivary glucose concentrations could be used as a minimally invasive technique to monitor glycemic control in diabetics [1]. Human saliva contains a large number of proteins and peptides that are easily accessible and may serve as a potential source of biomarkers to monitor changes that occur under pathological conditions [10]. They participate in the protection of the oral tissues, for instance, lysozyme, lactoferrin, lactoperoxidase, immunoglobulins, agglutinin, and mucins [11]. They also have metabolic functions, immune response, transportation, and several other cellular functions [5]. Salivary total protein is a vital component of saliva. Salivary protein, predominantly comprising proline-rich protein, mucin, amylase, immunoglobulins statherin and antibacterial factors, and they are responsible for most of the functions of saliva.

SALIVARY GLUCOSE LEVELS IN DIABETIC AND NON-DIABETIC PATIENTS

The use of saliva as a diagnostic resource has recently prompted studies aimed at determining characteristics of normality. There is a possibility of saliva substituting for blood in some laboratory tests, for example, in determining glycemia in the monitoring of DM, thereby being a non-invasive procedure and allowing sampling [2]. Higher glucose concentration favored the proliferation of microbes. Normal glucose levels in saliva range between 0.5 and $1.00 \mathrm{mg} / 100 \mathrm{~mL}$. They do not significantly affect the oral health or support the growth of microorganisms, but higher salivary glucose levels favor the proliferation of microorganism sand enhance their colonization on oral mucosal membrane and teeth [6]. In a study conducted by Abikshyeet et al., there was a positive correlation between salivary and serum glucose in diabetic patients [3]. A correlation between salivary and serum glucose was found in the controls as well. These correlations were found to be statistically significant. Hence, salivary glucose appears to be an indicator of serum glucose concentration in diabetic patients. Panchbai et al. showed that mean salivary glucose levels were higher in diabetics when compared to non-diabetics. This could be attributed to the carbohydrate-rich dietary pattern of the Indian population [1]. The dependence of salivary glucose on the glycemic status was also demonstrated by a study involving oral glucose tolerance test where the salivary glucose elevated twice the values within 60 min of glucose administration. This result showed that saliva was a means to clear out the exogenous glucose load taken for the test OGTT [8]. There is a divergence in values which may occur due to differences in methods utilized to collect saliva and in saliva collection [2]. Glucose is present in 
the saliva of normal individuals; however, the mechanism of its secretion is still obscure. Both paracellular and intercellular pathways have been proposed, but this is still an hypothesis rather than an established theory. Many authors have tried to explain the increased glucose content in the salivary secretion of diabetic patients. Some studies tried to show that the salivary glands act as filters of blood glucose that are altered by hormonal or neural regulation [4]. This increase in salivary glucose levels with an increase in blood glucose levels has been suggested to be attributed to "leakage" across the basement membrane of the glands, particularly the parotid gland when blood glucose levels increase beyond a threshold value [1]. Karjalainen et al. [12], Card et al. [13], and Bernardi et al. [14] demonstrated that the level of salivary glucose is augmented only when the concentration of blood glucose is elevated. Carda et al. observed that only diabetic individuals with fasting glycemia of $180 \mathrm{mg} / \mathrm{dL}$ and glycosylated hemoglobin higher than $8 \%$ showed elevated salivary glucose compared to those patients with poor metabolic control [13].

\section{SALIVARY PROTEIN LEVELS IN DIABETIC AND NON-DIABETIC} PATIENTS

Compared to serum, whole saliva is consistently under the influence of a hostile environment, with its proteins subjected to changes and modifications by host- and foreign-derived enzymes. This results in the possible generation and modifications of proteins in whole saliva. Most of the saliva proteins were resolved in acidic $\mathrm{pH}$ between 4 and 7 [5]. Studies have reported high protein levels in diabetics, while Panchbhai et al. estimated significant lower protein concentration in diabetics and emphasized protein utilization by other biochemical metabolic pathways, an overall systemic response to glucose intolerance. Insulin is known to have the potential to alter protein metabolism [6]. A study conducted by Kallapur et al. shows that total salivary protein levels in diabetic nonsmokers and diabetic smokers were found to be increased on comparison with controls. The increased salivary total protein in diabetics could be attributed to the increase in basement membrane permeability, allowing easy and increased passage of serum proteins into the whole saliva through salivary gland and gingival crevices [10]. With regard to genders of participation, lower mean salivary total protein levels were seen in diabetic males when compared to females [6].

\section{CONCLUSION}

DM is known to alter the composition of saliva. A few reported studies have shown an alteration of salivary constituents in DM [10]. There are definite changes in salivary composition, with increased levels of salivary glucose and total protein in diabetic and non-diabetic patients [4]. From this review, it can be concluded that salivary protein and glucose levels are increased in diabetic patients than in non-diabetic patients.

\section{REFERENCES}

1. Sashikumar R, Kannan R. Salivary glucose levels and oral candidal carriage in Type II diabetics. Oral Surg Oral Med Oral Pathol Oral Radiol Endod 2010;109:706-11.

2. Vasconcelos U, Sueli MM, Almeida PC, Soares TC. Comparitive study of the concentration of salivary and blood glucose in Type 2 diabetic patients. J Oral Sci 2010;52:293-8.

3. Abikshyeet P, Ramesh V, Oza N. Glucose estimation in the salivary secretion of diabetes mellitus patients. Diabetes Metab Syndr Obes 2012;5:149-54.

4. Kadashetti V, Baad R, Malik N, Shivakumar KM, Vibhute N, Belgaumi U, et al. Glucose level estimation in diabetes mellitus by saliva: A Bloodless revolution. Rom J Intern Med 2015;53:248-52.

5. Chan HH, Rahim ZH, Jessie K, Hashim OH, Taiyeb-Ali TB. Salivary proteins associated with periodontitis in patients with Type 2 diabetes mellitus. Int J Mol Sci 2012;13:4642-54.

6. Panchbhai AS, Degwekar SS, Bhowte RR. Estimation of salivary glucose, salivary amylase, salivary total protein and salivary flow rate in diabetics in India. J Oral Sci 2010;52:359-68.

7. Lasisi TJ, Fasanmade AA. Comparative analysis of salivary glucose and electrolytes in diabetic individuals with periodontitis. Ann Ib Postgrad Med 2012;10:25-30.

8. Afreen C, Rajeshwari SG, Arpitha G, Krishnananda P, Komal S, Keerthilatha MP. Glucose and antioxidants in the saliva of diabetic patients. Int J Curr Med Appl Sci 2015;7:50-3.

9. Javed F, Sundin U, Altamash M, Klinge B, Engström PE. Self-perceived oral health and salivary proteins in children with Type 1 diabetes. J Oral Rehabil 2009;36:39-44.

10. Kallapur B, Ramalingam K, Bastian, Mujib A, Sarkar A, Sethuraman S, et al. Quantitative estimation of sodium, potassium and total protein in saliva of diabetic smokers and nonsmokers: A novel study. J Nat Sci Biol Med 2013;4:341-5.

11. Van Nieuw Amerongen A, Bolscher JG, Veerman EC. Salivary proteins: Protective and diagnostic value in cariology? Caries Res 2004;38:247-53.

12. Karjalainen KM, Knuuttila ML, Käär ML. Salivary factors in children and adolescents with insulin-dependent diabetes mellitus. Pediatr Dent 1996;18:306-11.

13. Carda C, Mosquera-Lloreda N, Salom L, Gomez de Ferraris ME, Peydró A. Structural and functional salivary disorders in Type 2 diabetic patients. Med Oral Patol Oral Cir Bucal 2006;11:E309-14. 